\title{
Contribution of Awareness and Understanding in Legal and Ethics towards the Practice of Confidentiality amongst Counselors
}

\author{
Mohamad Bokhari ${ }^{1}$, Rosli Saadan ${ }^{1}$, Asiah Mohd Pilus ${ }^{2}$, Syed Najmuddin Syed Hassan ${ }^{3}$, Zanariah Jano ${ }^{1}$, Noriah \\ Mohd Ishak ${ }^{4} \&$ Zuria Mahmud ${ }^{5}$ \\ ${ }^{1}$ Centre for Languages and Human Development, Universiti Teknikal Malaysia Melaka, Malaysia \\ ${ }^{2}$ Sport Centre, Universiti Teknikal Malaysia Melaka, Malaysia \\ ${ }^{3}$ Centre for Teaching and Learning, Universiti Teknikal Malaysia Melaka, Malaysia \\ ${ }^{4}$ PERMATApintar Centre, Universiti Kebangsaan Malaysia, Malaysia \\ ${ }^{5}$ Faculty of Education, Universiti Kebangsaan Malaysia, Malaysia \\ Correspondence: Zanariah Jano, Centre for Languages and Human Development, Universiti Teknikal Malaysia \\ Melaka, Malaysia. Tel: 60-17-641-6822. E-mail: zanariahjano@utem.edu.my
}

Received: May 28, 2014 Accepted: June 14, 2014 Online Published: July 24, 2014

doi:10.5539/ass.v10n16p144 URL: http://dx.doi.org/10.5539/ass.v10n16p144

\begin{abstract}
Hitherto, the arising issue concerning counselors is whether counselors understand and aware on legal and ethical issues of confidentiality amongst them. The purpose of this study, hence, was to investigate the contribution of awareness, legal and ethical understanding on the confidentiality practice amongst counselors. A survey involving a sample size of 602 was conducted by sending questionnaires to counselors in Malaysia. The linear regression analyses yielded that only the awareness amongst counselors had significant contribution towards the practice of confidentiality. Other factors such as legal and ethical understanding did not show significant contribution. This study adds to the scarce literature on the upholding practice of confidentiality in counseling which is an essential element in the process. Moreover, the study is beneficial for researchers, counselors and educators in designing guidelines or codes of ethics in an organization. Future research should look into ways to uphold confidentiality practice amongst counselors from the perspectives of clients, teachers and the public as their views can form effective guidelines and procedures to confidentiality practice in Malaysia.
\end{abstract}

Keywords: university, websites, usability, compliance, cultural dimension

\section{Introduction}

\subsection{Background}

Under what circumstances confidential information should be disseminated is an issue that most counselors encounter in their counseling practices. Ethical and legal issues often surround the release of confidential data. Protecting confidentiality, hence, has always been a major responsibility of psychologists (American Psychological Association [APA], 1959, 1963, 1968, 1979, 1981, 1990, 1992, 2002). Extant literature on ethics reflect this; "confidentiality has long been viewed as "a cornerstone of the helping relationship" (Koocher \& Keith-Spiegel, 1998, p. 115); confidentiality is an issue affecting the values and beliefs of all groups who deal with a counselor (Susan \& Cowles, 1991); it is a crucial factor underlying the public trust in mental health practitioners (Haas \& Malouf, 2002); in the case of mental health practitioners, the bonds are important to ensure confidentiality issues of clients (Corey, Corey, \& Callahan, 2003). The APA Ethics Office emphasizes further its importance: "Confidentiality is a core value of our profession. It is, as they say, bred in our bones" (Behnke, 2005a, p. 76). Counselors have acknowledged the importance of protecting clients' confidence (Crowe, Grogan, Jacobs, Lindsay, \& Mark, 1985; Jagim, Wittman, \& Noll, 1978; Knapp \& Vande Creek, 1987). According to Mitchell, Disque dan Robertson (2002), confidentiality is essential to protect clients' interest in a way that a). Confidentiality is significant to build the trust in relationship between counselors and their students, b). Child's informed consent procedure should be widely spread so that it can protect the child's ethics and confidentiality interest and c). Revealing confidential information is allowed whenever there is a sign of students' safety being jeopardized (Allen \& Sidney, 2013). Hence, the importance of protecting confidentiality is highlighted in 
literature.

In fact, school counselors are required to control the violence in schools and welfare of students who are likely to become victims of crime (ASCA, 1998). Administrators, teachers and school counselors have a legal obligation to take action when students show signs of threatening or posing a danger to other students. In 1999, the United States Supreme Court has commented on the responsibility of the authorities of the schools in addressing violence in schools. United States Supreme Court asserts that school staff has been warned that they may be liable for failing to provide protection to students in danger by the students who are willing to do criminal violence. Thus, school counselors are required to update their knowledge on relevant court decisions on violence towards staff and students at the school. Even administrators, staff and school counselors have been brought to court for failing to provide protection or warnings to other students on the dangers of terror threat ahead of students (Hermann \& Finn, 2002).

Today, school counselors are faced with the urgent needs for counseling sessions covering cases of stress, suicide, pregnancy, drugs, school violence and child abuse. To address this concern, the school counselor should have clinical skills and awareness of legal and ethical depth prior to taking any action (Herlihy, Gray, \& McCollum, 2002). In fact, school counselors face many problems on legal issues (Corey, Corey, \& Callanan, 1998). For example, failure to report suspected cases of abuses against children will result in legal prosecution of criminal and civil proceedings against the school counsellor. In the United States, the rate of suicide among adolescents under the age of 20's has increased over 300\% since 1950's. Schools in the United States are required to make guidelines for suicide prevention and crisis management. This is a challenge to the ethical and legal issues to a counselor and even to the faculty, administration and school staff (Capuzzi \& LPC, 2002).

\subsection{Relevant Scholarship}

\subsubsection{The Code of Ethics}

Various codes of ethics have been developed for counselors' guidance. Code of ethics includes the normative punishment of society's behavior. The punishment includes significant elements of good and bad characteristics among the society but may not be enforced by the law. However, not all of the law-breaking activities are considered as crimes though the code may be transgressed (Corey, Corey, \& Callahan, 2003). National Association of Social Workers (henceforth, NASW) (1999) produced a NASW Code of Ethics (1999) which informs the professional ethics of the social workers and guides the counselors in terms of managing his or her duties professionally. Informed consent is part of the ethical and legal principles which requires the counselor to inform the client in facing potential risk, benefits and alternatives during the counseling session (Glosoff \& Pate, 2002; William, 2012). Furthermore, principles of counseling ethics also aim to guide the counselors to make an appropriate decision whenever the situation has created ethical dilemma concerning moral values. The principles are known as the golden Five which are autonomy, beneficence, non-maleficence, justice and fidelity. These principles act as guidelines for counselors in order to make decision and justification on a problem that creates ethical dilemma especially the ethics involving confidentiality (Cottone \& Tarvydas, 1998).

According to American Association for Counseling and Development (henceforth, AACD, 1988) section "A": "General, paragraph six, states that when a counselor reveals an information or statement to the public, the laymen and colleagues, the counselor should be accountable towards the content of his or her statement. The information revealed by the counselor should be correct and client's identification should be veiled. Section "B": "Interaction of Counseling"; paragraph two states that a counselor must maintain confidentiality. All forms of client's record which are not important should be destroyed. The counselor is accountable to keep information during the counseling session confidential. In the group counseling session, counselor should place ethical confidentiality at the top of the priority. Any form of revealed information at a counseling session is prohibited. In addition, Corey, Corey and Callanan (2003) and APA (1992) have divided the legal confidential ethics into the following categories: a). Privileged Communication, b). Privacy, c). The Duty to Warn and to Protect, d). Informed Consent and e). Access to Records.

Moreover, ethics of confidentiality in Counseling Association of Malaysia (henceforth, PERKAMA) states that counselors should maintain confidentiality of the information obtained from clients during the counseling session unless the information is harmful to clients and others, and above the demands of law must be followed with enthusiasm (PERKAMA Review, 2008, p. 5). Without maintenance on the ethics of confidentiality, the counselor can simply use the weaknesses of the client or take advantage of the interest itself. Thus, confidentiality is necessary to protect the interests of the clients. Indeed, confidentiality is significant in creating the trust on the relationship between a counselor and a client (Mitchell, Disque, \& Robertson, 2002).

In order to perform the tasks as a reliable counselor and gain the trust of clients, a counselor should be alert of 
ethical confidentiality. Counselors should understand and practice ethical confidentiality because clients in distress are easy to be manipulated. Therefore, lacking of understanding and awareness of the ethical confidentiality, counselors can manipulate the client's weaknesses for their own benefits. Furthermore, counselors must acquire a high standard of competence in the knowledge, experience and counseling skills in order to maintain ethical confidentiality based on the counseling ethical code (Biggs \& Blocher, 1987). Therefore, without the counseling qualification, experience and skills, counseling services can fail and the clients will ignore the counseling rooms. In fact, at present, conflicts of the counseling ethics and ethical confidentiality among the counseling profession can easily be solved based on the ethical codes outlined. If the ethical codes are followed, the counseling profession could be stabilized at a high standard (Noriah, Zuria, \& Amla, 2003).

\subsubsection{Past Studies in Ethical Issues in Confidentiality Practice}

Some studies pertain to the breach of confidentiality exist in extant literature. Gottfried (2000) finds that there are 41 cases of informed consent violation. Thirty cases of violations of informed consent by social workers occur when counselor fails to discuss the policies with client; nine cases involving failure to discuss pertaining to fees, bills or other policies payment; eight cases involving 'the worker proceeds with some action over the client's objections such as 'taping a session', divulging information of a case although the client has not given permission to it. Meanwhile, there are three cases of 'consent' which are obtained through unfair means.

The Ethics and Standards of Practice Committee of the Minnesota Child Psychologists has conducted a study consists of six clinical child psychologists. 1068 questionnaires have been circulated to (a) registered psychologists under the Board of Psychologists, Minnesota (b) school psychologists under the Special Education Section, Department of Learning, Family and Child, Minnesota. About 354 (33\%) questionnaires are returned and the study shows that protecting the adult privacy could strengthen the confidential ethics. Around 3.2\% $6.5 \%$ of the public state that counselors have reported about client's immoral behaviour to other parties. In fact, $20.9 \%$ from the public state that the breaches of child's record occur during a therapy session and $18.8 \%$ of the public stress that parent's medical report data are also found inside the child's record (Alexander, 1997).

The Gallup Organization under the Institute for Health Freedom, (Zoutman, Ford, \& Bassili, 2004) finds the majority of the respondents aged between 18 to 35 years old (95\%) are very keen on ethical confidentiality. In fact $75 \%$ of the female adults surveyed are aware that ethical confidentiality is the main factor to gain the client's trust among the counsellors. Sealander, Schwiebert, Oren, and Weekley (1999) analyse teenage students' opinion in relation to the importance of ethical confidentiality and find that $35 \%$ of the students agree that ethical confidentiality is very important. Meanwhile, $46 \%$ of the students view that ethical confidentiality as important only. Overall, the respondents agree that ethical confidentiality should be breached to their parents, police and teachers whenever a clear cut case appears as a symptom of danger towards the student's safety. Furthermore, Mitchell, Disque and Robertson (2002) find that ethical confidentiality is essential to protect the client's confidentiality. In addition, the ethical confidentiality is significant to develop the trust between counselors and client.

However, confidentiality concept is easy to understand but difficult to be implemented by counselors and psychologists due to complex factors (Noriah, 2004). School counselors face many legal issues and the failure to report the suspected case of child abuse could lead to civil and criminal suit (Corey, Corey, \& Callahan, 1998). Mohd Noh (2001) finds that clients prefer to meet a close friend to discuss their problems. The second person that clients will prefer to meet is their school-mate; the third person is their parents, while the counselor will be their seventh or the tenth option. On the same note, Snyder, Hill and Derksen (1972) state that a study among 181 university students shows that their peers are the first reference point for the students' personal and social problems, a close relative to be the second option and services offered by the faculty as well as the psychologist to be their final choice. According to Isaacs and Stone (1999), confidentiality is an issue to gain the client's trust. Generally, students would not seek counseling services if the confidential ethics are not upheld and practiced by counselors. Biggs and Blocher (1987) state that counselors must be aware of the ethics while conducting the counseling services. Moreover, conflicts within the profession could be avoided and would be well addressed according to the counseling guidelines. Thus, the stability in the profession will prevail. Generally, the code of ethics is to guide counselor on 'what ought to be done and what ought not to be done' as a professional counselor during their counseling session (Noriah, Zuria, \& Amla, 2003). The aim of the present study was to investigate the influence of awareness, legal and ethics understanding on the confidentiality practice of ethics amongst counselors. 


\subsubsection{Theoretical Framework}

According to Badzek, Mitchell, Marra and Bower (1998), in order to handle confidential information, a counselor requires an ethical understanding, awareness, practice, knowledge and skills to make decisions. Thus, education, understanding, awareness and practice of secrecy are essential elements in the framework for the present study. The theoretical framework is developed as outlined in Figure 1.

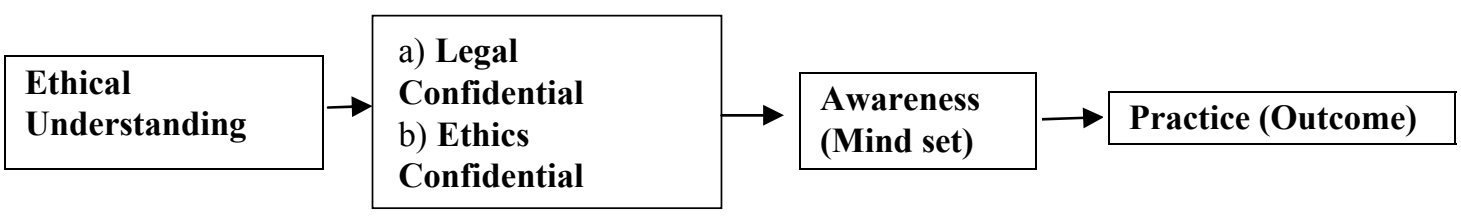

Figure 1. Theoretical framework

According to Badzek et al. (1998), breaching the confidential information needs the knowledge, awareness and ethical confidential practice competence. In this study, the process to be examined is that if a counselor is found breaching ethical confidentiality, the counselor must strengthen the knowledge of his or her ethics confidentiality. When the knowledge of ethical confidentiality is intact, the process of ethical confidential awareness will develop in the counselor's mind and soul. Thus, when these two elements of ethical confidentiality namely knowledge and awareness are merged, the ethical confidentiality practice will easily be implemented. Moreover, Stufflebeam, Foley, Gephart, Guba, Hammond, Merriman and Provus (1971) assert that to practice the ethical confidentiality, counselor should acquire the input knowledge and information regarding the issues that prevail in the environment. Thus, a vast information and knowledge regarding ethical confidentiality will lead to awareness in implementing a high level of ethical confidentiality practice among counselors.

\subsubsection{Research Questions}

This study utilises the following research questions:

1) Does awareness influence the confidentiality practice of ethics amongst counselors?

2) Does legal understanding influence confidentiality practice of ethics amongst counselors?

3) Does ethics understanding influence confidentiality practice of ethics amongst counselors?

\section{Method}

This section illustrates the sample, instrument, data collection and content validity and reliability.

\subsection{Sample}

A quantitative analysis was used to test the research model through a cross-section survey method. 1000 survey questionnaires were sent out to randomly selected counselors in several states in Malaysia. The respondents are graduated either in the Diploma in Counseling, Masters in Counseling (Guidance and Counseling) or Doctorate in Counseling. 602 completed questionnaires were returned.

\subsection{Instrument}

The questionnaire was divided into five sections. Overall, 56 items were to be answered by the respondents. The first section consisted of questions regarding the demographic characteristics of the respondents. The second section consisted of 21 items regarding the knowledge of legal confidentiality. The third section consisted of 19 items regarding the knowledge of ethical confidentiality. The fourth section comprised 9 items regarding the confidentiality awareness. Finally, the fifth section comprised 7 items regarding the practice of confidentiality. The instrument used in this survey was developed based on the literature. Meanwhile, the instruments have been approved by thirteen (13) experts and experienced counselors in the counseling field for establishing face validity of the items. The five-point Likert scale ranging from 1 (strongly disagree) to 5 (strongly agree) was used for the questions to indicate a degree of agreement or disagreement with each of a series of statements related to the stimulus objects.

\subsection{Data Collection and Analysis}

The questionnaire was pre-tested through the pilot study within the counselors in three states in Malaysia namely Melaka, Selangor and Perak. The pilot study resulted in the minor adjustment to the vagueness of wording and sequence of the questions. A subtraction of seventy three (73) items from 129 original items to measure ethical confidentiality was based on the experts' suggestion during the pilot study. The revised questionnaire was then 
administered to respondents. The data were analyzed by examining the distribution of responses based on descriptive analyses; frequencies and percentages. A statistical application namely regression analysis was used to examine the data. Participants in the study were counselors in institutions of higher learning, school counselors, counselors in government and private sectors. These groups are chosen because of the nature of their jobs as counselors.

\subsection{Content Validity}

Content validity of the questionnaire was established by reviewing existing literature. Most of the items intended to measure the variables in this study were adopted from the literature and constructed by the researcher. Opinions from the experts were taken into consideration when revising the questionnaire. Items which were below .50 for the Cronbach Alph were dropped. According to Wiersma (2000), items validity index of between 0.7600 and 0.9200 shows that the content validity has a high Cronbach Alpha. Hence, the major aspects of the topic were adequately covered by the items included in the questionnaire.

\subsection{Reliability}

The survey instrument measured 'the understanding and awareness of counselor regarding the legal and ethical issues of confidentiality among the counseling practitioners. The Confidentiality Ethics Inventory was invented and Cronbach's $\alpha$ (Cronbach, 1951) was used to measure the reliability. Alpha coefficients for the factors influencing the confidentiality practice of ethics amongst counselors were 0.97 . This shows that those items have high and consistent reliability value of Cronbach's $\alpha$ (Wiersma, 2000). According to Hair, Anderson, Tatham and Black (1998); Robinson, Shaver and Wrightsman (1991), the reliability measure is between 0 to 1; the value between 0.60 to 0.70 is the lowest value which is still acceptable. Hence, the internal reliability of the measures used is good.

\section{Findings and Discussion}

The findings discuss the demographic profile and the tested variables. In addition, the influence of demographic profile on the factors was also determined through regression test.

\subsection{Demographic Profile}

The samples were counselors from various agencies like schools, government and private agencies, and institutions of higher learning at several states in the Peninsular of Malaysia. In terms of place of services, 18 respondents $(36 \%)$ served at the secondary school, 4 respondents $(8 \%)$ at the primary school, 6 respondents $(12 \%)$ at rehabilitation center, 1 respondent $(2 \%)$ at the Juvenile Centre, 3 respondents $(6 \%)$ at the Charity homes, and 3 respondents $(6 \%)$ at other places such as the institutions of higher learning and the Malaysian Arm Forces. Meanwhile, 22 respondents (44\%) served as counselors between 1 year to 4 years, 20 respondents $(40 \%)$ between 5 years to 9 years, and finally 8 respondents $(16 \%)$ more than 10 years. Furthermore, 38 respondents (76\%) graduated with Bachelor of Guidance and Counseling, 8 respondents (16\%) Master of Guidance and Counseling, and 4 respondents (8\%) Bachelor of Psychology and Communication, Bachelor of Education Psychology. Meanwhile, in terms of the counselors' hours of counseling sessions and activities, 6 respondents (12\%) engaged below 1,000 hours, 20 respondents (40\%) between 1,000 hours to 4,999 hours, 16 respondents (32\%) between 5,000 hours to 9,999 hours, 6 respondents (12\%) between 10,000 hours to 14,999 hours, and 2 respondents (4\%) more than 15,000 hours.

\subsection{Awareness, Legal and Ethical Understanding}

Some contributions were exerted by the awareness on practice of confidential ethics amongst counselors as illustrated in Table 1,2 and 3. Only the awareness factor contributed towards the practice of confidential ethics amongst counselors. Other factors such as legal understanding and ethics understanding did not show any significance on the practice of confidential ethics. Regression model showed that the awareness variance is significant $\mathrm{F}(1,600)=45.751, \mathrm{p}=.000(\mathrm{p}<.005)$.

Regression equation is shown as follows.

$$
\mathrm{Y}=1.948+0.274 \mathrm{X}^{1}+.184
$$

Y: practice of confidential ethics;

$\mathrm{X}^{1}$ : awareness of counseling;

Constant 1.948; Standard Error .184. 
Table 1 . Model summary

\begin{tabular}{lllll}
\hline Model & $\mathrm{R}$ & R Square & Adjusted R Square & Std. Error of the Estimate \\
\hline 1 & $.274^{\mathrm{a}}$ & .075 & .070 & .49763 \\
\hline
\end{tabular}

a. Predictors: (Constant), awareness, legal understanding and ethics understanding;

b. Dependent Variable: practice of confidential ethics.

Table 2. ANOVA

\begin{tabular}{llllll}
\hline Model & Sum of Squares & df & Mean Square & F & Sig. \\
\hline Regression & 11.343 & 1 & 11.343 & 45.751 & $.000^{\text {a }}$ \\
1 Residual & 148.756 & 600 & .248 & & \\
Total & 160.099 & 601 & & & \\
\hline
\end{tabular}

a. Predictors: (Constant), awareness, legal understanding and ethics understanding;

b. Dependent Variable: practice of confidential ethics.

Table 3. Coefficients

\begin{tabular}{|c|c|c|c|c|c|}
\hline \multirow{2}{*}{ Model } & \multicolumn{2}{|c|}{ Unstandardized Coefficients } & \multirow{2}{*}{$\begin{array}{l}\text { Standardized Coefficients } \\
\text { Beta }\end{array}$} & \multirow{2}{*}{$\mathrm{t}$} & \multirow{2}{*}{ Sig. } \\
\hline & $\mathrm{B}$ & Std. Error & & & \\
\hline 1 (Constant) & 1.948 & .184 & & 10.596 & .000 \\
\hline Legal understanding & -.111 & .069 & -.065 & -1.613 & .107 \\
\hline Ethics Understanding & .001 & .061 & .001 & .013 & .990 \\
\hline Awareness & .361 & .053 & .266 & 6.764 & .000 \\
\hline
\end{tabular}

a. Dependent Variable: Practice of confidential ethics.

The results showed that the awareness of confidential ethics amongst counselors (Beta $=.266, t=6.764, p=.000$ ) was a significant predictor for the practice of confidential ethics. The awareness of confidential ethics contributed about $7.0 \%\left(\mathrm{R}^{2}=.070\right)$ towards the practice of confidential ethics variance. When the score of the practice of confidential ethics increased a unit, the constant score of the awareness amongst counselors increased by .274 .

\subsection{Discussion}

The results show that only the counseling awareness of confidential ethics amongst counselors has a significant contribution towards the practice of confidential ethics. This is in-line with the study of Ayub's (2010) which find that the importance of understanding and maintaining the awareness of ethics confidentiality among counselors is formidable, and consequently it would create a bench marking to the effectiveness of the counseling services provided to the clients. However, to maintain awareness in ethical confidentiality in counseling is difficult because high commitment is needed (Dahir, Hardy, Ford, \& Morrissey, 2005). The counselors' awareness in upholding and protecting the ethics confidentiality is a must in the counseling processes (Glosoff \& Pate, 2002). The awareness to practice ethics confidentiality among counselors will generate an open communication between counselors and their clients. Thus, it would become an element of accountability and integrity in practicing ethics confidentiality among counselors. Consequently, it would lead to client's trust towards the counselors (Badzek, Mitchell, Marra, \& Bower, 1998; Hamilton, 1999).

In fact, this study shows that the client's informed consent and issues discussed during the counseling session are taken seriously and protected securely by the counselors. The counselors are found to have a good understanding and awareness about the importance of informed consent. Informed consent is an issue that involves legal and ethical implication of ethics confidentiality to the counselors (Elkin, 2001). Counselors' awareness, hence, is an essential element in enhancing the relationship between counselors and clients.

Other factors such as legal understanding and ethics understanding do not contribute to the practice of confidential ethics. Previous studies show that counselors with a high commitment to uphold ethics confidentiality will encourage clients to seek the counseling services frequently, because they have the instinct 
that their privacy are well protected by the counselors (Samuel, 1996; Fisher, 2008; Fisher, 2013). However, the issue of student counselors often shares their problems with others or with colleagues is a violation of the confidentiality of the counseling code of ethics which has occurred to date (Sapora, 2010). Even the counselors know the code of ethics of confidentiality issued by the Board of Counselors Malaysia under Counselor Regulations (Conduct and Discipline, 1999), which states that "respect the personal rights of clients, and keep all the information obtained during counseling as confidential unless, at the discretion of the counselor information obtained or is deemed to endanger the client or other person in the environment" (the Counselors Act 1998, Act 580 pp. 81-86). Similarly, the counselor should understand and realize that they are not permitted to disclose information about clients in writing, lectures, or in the public media unless the individual or organization has authorized in writing or there is a legal ethics, legal or other authorized to do so (American Psychological Association's/APA's 1992). Hence, lacking legal and ethics understanding is an issue which needs to be overcome in order to gain clients' trust in counseling process.

\section{Conclusion}

In conclusion, this study shows that the clients' informed consent and issues discussed during the counseling sessions are taken seriously and protected securely by the counselors. The counselors have the awareness towards the practice of confidential ethics amongst counselors. However, other factors such as legal understanding and ethics understanding did not show any significance on the practice of confidential ethics which is detrimental to the relationship between counselor and client. This study adds to the literature because there are few studies discussing about the upholding confidentiality practice in counseling which is an essential element in the counseling process. Moreover, this study is beneficial for researchers, counselors and educators in designing guidelines or code of ethics in the organizations. Future research should look into ways to uphold confidentiality practice amongst counselors from the perspectives of clients, teachers and the public as their views can form effective guidelines and procedures to ethical practices among counselors in Malaysia.

\section{Acknowledgements}

This work was supported in part by Universiti Teknikal Malaysia Melaka.

\section{References}

Ahmad, A. (2010). Confidential Ethics: How far... A Critical Analysis from the Desk of Student Affairs. Human Development Sector.

Allen, R. D., \& Bloch, S. (2013). Informed consent and the psychiatric patient. Journal of Medical Ethics, 39(2).

American Psychological Association. (1992). Ethical Principles Of Psychologists And Code Of Conduct, 47, 1597-1611.

American School Counselor Association (ASCA). (1998). Ethical Standards for School Counselors (Revised June 25, 1998). Retrieved from http://www.schoolcounselor.org/content.cfm?L1=103

Badzek, L. A., Mitchell, K., Marra, S. E., \& Bower, M. M. (1998). Administrative Ethics and Confidentiality Privacy Issues. Online Journal of Issues in Nursing. Retrieved January 4, 2014, from http://www.nursingworld.org/MainMenuCategories/ANAMarketplace/ANAPeriodicals/OJIN/TableofConte nts/Vol31998/No3Dec1998/PrivacyIssues.aspx

Baki, M. S. (2005). Counseling element in the Management of human resource. 2nd Counseling Seminar, Ministry of Education Malaysia. City Bayview Hotel, Langkawi, Kedah, Malaysia: 30 Mei-2 Jun 2005.

Capuzzi, L. P. C. D. (2002). Legal and Ethical Challenges ini Counseling Suicidal Students. ASCA*\Profesional School Counseling * 6:1 October 2002.

Corey, G., Corey, M. S., \& Callanan, P. (1998). Issues \& Ethics in the Helping Professions (5th ed.). Brooks/Cole Publishing Company: Monterery, California.

Corey, G., Corey, M. S., \& Callanan, P. (2011). Issues \& Ethics in the Helping Professions (8th ed.). Brooks/Cole Publishing Company: Monterery, California.

Dahir, C., Hardy, D., Ford, D., \& Morrissey, D. (2005). The New York State Model for Comprehensive K-12 School Counseling Programs. Leicester, NY: New York State School Counselor Association.

Elkin, S. (2010). Informed consent: Requirements for legal and ethical practice. Physiotherapy Theory and Practice. Taylor \& Francis.

Fisher, M. A. (2008). Protecting Confidentiality Rights: The Need for an Ethical Practice Model. American Psychologist, 63(1), 1-13. http://dx.doi.org/10.1037/0003-066X.63.1.1 
Fisher, M. A. (2013). The Ethics of Conditional Confidentiality. A Practice Model for Mental Health Professionals: Oxford University Press.

Glosoff, H., \& Pate Jr., R. (2002). Privacy and confidentiality in school counseling. Professional School Counseling, 6, 20-27.

Hair, J. E., Anderson, R. E., Tatham, R. L., \& Black, W. C. (2009). Multivariate data analysis. $7^{\text {th }}$ Upper Saddle River: Prentice Hall.

Hamilton, J. C. (2010). The Ethics of Conducting Social-Science Research on the Internet. Chronicle of Higher Education, 46(15).

Herlihy, B., Gray, N., \& McCollum, V. (2002). Legal and Ethical Issues in School Counselor Supervision. ASCA* Professional School Counseling* 6:1 October 2002.

Hermann, M. A. (2002). A Study of Legal Issues Encountered by School Counselors and Perceptions of Their Preparedness to Respond to Legal Challenges. ASCA Professional School Counseling, 6(1).

Hermann, M. A., \& Finn, A. (2002). An Ethical and Legal Perspective on the Role of School Counselors in Preventing Violence in Schools. Professional School Counseling, 6(1), 46-54.

Ishak, N. M. (2004). Confidentiality: Ethical, Legal and Practical Implication for Malaysian Counselors. Journal PERKAMA No. 2004.

Mitchell, R., Disque, G., \& dan Robertson, P. (2002). When Parents Want to Know: Responding to Parental Demands for Confidential Information. Professional School Counseling, American School Counselor Association, 6(2).

O'Connell, W. P. (2012). Secondary School Administrators' Attitudes toward Confidentiality in School Counseling. NASSP Bulletin, 96(4), 350-363. http://dx.doi.org/10.1177/0192636512466936

Pope, K. S., Tabachnick, B. G., \& Keith-Spiegel, P. (1987). Ethics of practice: The beliefs and behaviors of psychologists as therapists. American Psychologist, 42, 993-1006. http://dx.doi.org/10.1037/0003-066X. 42.11 .993

Sealander, K. A., Schwiebert, V. L., Oren, T. A., \& Weekley, J. L. (1999). Confidentiality and the Law. ASCA Professional School Counseling, 3(2).

Seng, L. S. (2003). Legal and Ethical Issues in Group Counseling in the Malaysian Context. LLB, LLM, MBA Advocate \& Solicitor High Court, Malaya, Certified Mediator.

Sipon, S. (2010). School Counselor Professionalism: A Survey. School of Psychology and Social Work: University of Malaysia Sabah/10 July 1997.

Snyder, J. F., Hill, C. E., \& Derksen, T. P. (1972). Why some students do not use university counseling facilities. Journal of Counseling Psychology, 19, 263-268. http://dx.doi.org/10.1037/h0033075

Stufflebeam, D. L., Foley, W. J., Gephart, W. J., Guba, E. G., Hammond, R. I., Merriman, H. O., \& Provus, M. M. (1971). Education evaluation and decision making. Illinois: Peacock.

Susan, C. V., \& Cowles, J. (1991). Counselor self-awareness and client confidentiality: A relationship revisited. Elementary School Guidance \&Counseling, 25, 269-276.

Wiersma, W. (2009). Research Methods in Education an Introduction (9th ed.). USA: Pearson Education Company.

Zoutman, D. E., Ford, B. D., \& Bassili, A. R. (2004). The confidentiality of patient and physician information in pharmacy prescription records. Canadian Medical Association, Department of Pathology and Molecular Medicine and the Department of Community Health and Epidemiology, Queen's University, Kingston, Ont.

\section{Copyrights}

Copyright for this article is retained by the author(s), with first publication rights granted to the journal.

This is an open-access article distributed under the terms and conditions of the Creative Commons Attribution license (http://creativecommons.org/licenses/by/3.0/). 